\title{
Trichoderma spp. dan Penicillium spp. dari Tanah Rizosfer Lahan Rawa Lebak dalam Menginduksi Ketahanan Tanaman Cabai Terhadap Serangan Penyakit Rebah Kecambah
}

\author{
Induced Resistance to Damping-off Disease in Chili Using \\ Trichoderma spp. and Penicillium spp. Isolated from Soil Rhizosphere \\ in Lowland Swampy Area
}

\author{
Ahmad Muslim*, Syahri, Harman Hamidson, Abdullah Salim \\ Universitas Sriwijaya, Ogan Ilir 30662
}

\begin{abstract}
ABSTRAK
Mikroba yang berasosiasi dengan rizosfer sangat penting bagi pertumbuhan tanaman dan dapat melindungi tanaman dari penyakit. Penelitian dilakukan untuk menentukan kemampuan isolat cendawan Trichoderma spp. dan Penicillium spp. yang diisolasi dari rizosfer di lahan rawa lebak dalam mengendalikan penyakit rebah kecambah yang disebabkan oleh Rhizoctonia solani pada tanaman cabai. Trichoderma spp. dan Penicillium spp. diaplikasikan dalam bentuk inokulum dengan bahan pembawa dedak, jagung, dan merang padi. Aplikasi kedua isolat cendawan pada pembibitan tanaman cabai selama 2 minggu mampu menginduksi ketahanan tanaman cabai terhadap infeksi $R$. solani. Perlakuan Trichoderma spp. dan Penicillium spp. dapat menekan insidensi penyakit berturut-turut sebesar 61.5$100 \%$ dan $46.2-100 \%$, dan keparahan penyakit berturut-turut sebesar $50-100 \%$ dan $30-95.9 \%$. Hasil tersebut menunjukkan potensi Trichoderma spp. dan Penicillium spp. sebagai agens biokontrol untuk mengendalikan penyakit rebah kecambah pada tanaman cabai.
\end{abstract}

Kata kunci: induksi ketahanan, insidensi penyakit, keparahan penyakit, Rhizoctonia solani

\begin{abstract}
Soil microbes associated with rhizosphere are important for promoting plant growth and inducing resistance to diseases. The research was conducted to study the ability of Trichoderma spp. and Penicillium spp. isolated from rhizosphere in lowland swampy area for controlling damping-off disease caused by Rhizoctonia solani Khun. Trichoderma spp. and Penicillium spp. were cultured in bran, corn meal, and rice straw containing media and applied as inoculum to 2-weeks old seedlings. Application of two fungi isolates effectively induced resistance of chili plants to damping-off disease. Trichoderma spp. and Penicillium spp. were significantly reduced disease incidence by $61.5-100 \%$ to $46.2-100 \%$, respectively and disease severity by $50-100 \%$ and $30-95.9 \%$, respectively. This experiment showed the potential of Trichoderma spp. and Penicillium spp. as biocontrol agents to control damping-off disease on chili.
\end{abstract}

Key words: chili, disease incidence, disease severity, induced resistance, Rhizoctonia solani

\footnotetext{
*Alamat penulis korespondensi: Jurusan Hama dan Penyakit Tumbuhan, Fakultas Pertanian, Universitas Sriwijaya Jalan Raya Palembang-Prabumulih Km 32, Indralaya, Ogan Ilir 30662

Tel: 0711-580663, Faks:0711-580059, Surel: limpal2003@yahoo.com
} 


\section{PENDAHULUAN}

Daerah rizosfer merupakan daerah yang sangat penting bagi pertumbuhan tanaman dan juga daerah pertahanan yang paling penting dari serangan patogen. Mikroorganisme yang berasosiasi dan hidup di sekitar akar (rizosfer dan rizoplen) sangat penting bagi pertumbuhan tanaman dan juga dalam ekosistem tanah. Shivana et al. (1996) melaporkan bahwa cendawan steril, Phoma, Trichoderma, Fusarium, dan Penicillium merupakan cendawan rizosfer yang efektif dalam menekan berbagai penyakit rebah kecambah dan layu fusarium pada tanaman mentimun, di samping itu cendawan tersebut juga dapat memacu pertumbuhan tanaman sehingga digolongkan sebagai cendawan pemacu pertumbuhan tanaman (PPT). Merra et al. (1994) membuktikan bahwa, cendawan tersebut mempunyai kemampuan mengolonisasi akar mentimun dengan baik dan mampu menginduksi ketahanan tanaman terhadap penyakit antraknosa.

Eksplorasi cendawan rizosfer dari daerah rawa lebak yang memiliki potensi sebagai penginduksi ketahanan tanaman belum banyak dilaporkan. Penelitian mengenai cendawan PPT yang memiliki kemampuan melindungi tanaman dari penyakit, baik sebagai agens biokontrol ataupun penginduksi ketahanan tanaman akan sangat berguna dalam mendukung pengembangan pengendalian ataupun pengelolaan penyakit secara terpadu dan berkelanjutan, khususnya di daerah rawa lebak. Penelitian ini bertujuan menentukan kemampuan cendawan Trichoderma dan Penicillium dalam menginduksi ketahanan tanaman cabai terhadap penyakit rebah kecambah yang merupakan penyakit penting pada tanaman cabai di lahan rawa lebak.

\section{BAHAN DAN METODE}

\section{Inokulum Cendawan Rizosfer dan Patogen}

Inokulum cendawan Trichoderma spp. dan Penicillium spp. yang digunakan diisolasi dari tanah rizosfer lahan rawa lebak di Kabupaten Ogan Ilir, Sumatera Selatan yang sudah diuji kemampuannya sebagai cendawan PPT (Muslim et al. 2006). Isolat patogen $R$. solani diisolasi dari akar tanaman cabai yang terserang penyakit rebah kecambah. Masing-masing cendawan Trichoderma spp., Penicillium spp., dan Rhizoctonia solani disiapkan dengan cara yang sama dalam bentuk inokulum yang menggunakan substrat campuran dedak, jagung, dan merang padi kering dengan perbandingan masing-masing volume yang sama. Masing-masing isolat cendawan ditumbuhkan pada medium agaragar dekstrosa kentang (ADK) selama 3 hari pada suhu ruangan. Sebanyak 5 koloni miselium (ø $5 \mathrm{~mm}$ ) dari masing-masing biakan dipotong dari ujung pertumbuhan yang termuda dan diletakkan ke dalam $80 \mathrm{~g}$ substrat campuran dedak, jagung, merang padi basah (dicampur air distilasi dengan perbandingan 1:0.8 b/v campuran dedak, jagung, dan merang padi kering:air distilasi) yang sudah disterilkan dengan autoklaf di dalam botol erlemneyer $(500 \mathrm{~mL})$. Masing-masing biakan diinkubasikan selama 10-14 hari pada suhu ruangan. Biakan digoyang setiap hari supaya kolonisasi cendawan pada subsrat merata. Substrat yang terkolonisasi oleh masingmasing cendawan dikering anginkan selama 7 hari dan disimpan pada suhu $4{ }^{\circ} \mathrm{C}$ sebelum digunakan (Muslim 2003).

\section{Uji Induksi Ketahanan}

Prinsip induksi ketahanan ialah perlindungan tanaman secara tidak langsung tanpa kontak langsung antara agens hayati dan patogen. Uji induksi ketahanan pada tanaman cabai terhadap penyakit rebah kecambah ini dilakukan mengikuti Cardosa dan Echandi (1987) yang dimodifikasi. Benih tanaman cabai ditanam pada wadah yang diisi tanah yang telah diinfestasi dengan Trichoderma spp. dan Penicillium spp., dengan konsentrasi 2\% (b/b). Tanah sebagai media tumbuh berasal dari lahan rawa lebak. Bibit dibiarkan tumbuh selama 2 minggu, kemudian bibit dicabut dengan hati-hatiuntuk menghindari akar tanaman patah atau rusak. Trichoderma spp., dan Penicillium spp., yang mengolonisasi akar tersebut dimatikan dengan 
merendam akar bibit dalam larutan $\mathrm{NaOCl} 1 \%$ selama 1 menit lalu alkohol $70 \%$ selama 1 menit. Bibit tersebut ditanam kembali pada tanah yang telah diinfestasi $R$. solani dengan konsentrasi $1 \%(b / b)$ dari bobot medium tanam. Untuk memastikan Trichoderma spp., dan Penicillium spp., sudah tidak berasosiasi dengan akar tanaman, akar yang telah disterilisasi permukaannya, dipotong-potong sepanjang $1 \mathrm{~cm}$, kemudian potongan akar diletakkan pada medium agar-agar air atau medium ADK dan diamati pertumbuhan agens hayati.

Peubah yang diamati pada uji induksi ketahanan ialah insidensi penyakit dan persentase keparahan penyakit. Insidensi dan keparahan penyakit dihitung dengan rumus:

$$
\mathrm{M}=\frac{\mathrm{n}}{\mathrm{N}} \times 100 \% \text {, dengan }
$$

$\mathrm{M}$, insidensi penyakit; $\mathrm{n}$, jumlah bibit mati; $\mathrm{N}$, jumlah seluruh bibit yang disemai.

$$
I=\frac{\sum(n \times v)}{Z \times N} \times 100 \% \text {, dengan }
$$

$I$, keparahan penyakit; $n$, jumlah bibit yang terserang; $Z$, harga numerik dari nilai kategori tertinggi; $N$, jumlah benih yang disemai; $v$, harga numerik dari setiap nilai kategori (05): 0, tidak ada penyakit; 1 , lesio muncul pada leher akar sepanjang $1 \mathrm{~mm}$; 2, lesio cokelat sampai cokelat gelap sepanjang 2-10 mm mengelilingi akar; 3, lesio cokelat gelap sepanjang 10-25 mm ketika miselium mengolonisasi koleoptil; 4, >25 mm area akar menjadi hitam dan busuk pada koleoptil; 5, bibit busuk secara menyeluruh atau bibit mati.

Persentase penghambatan terhadap insidensi dan keparahan penyakit dihitung berdasarkan rumus sebagai berikut:

Persentase penghambatan $=\frac{\mathrm{K}-\mathrm{P}}{\mathrm{K}}$ X $100 \%$, dengan

$\mathrm{K}$, nilai insidensi penyakit atau keparahan penyakit pada perlakuan kontrol; $\mathrm{P}$, nilai insidensi penyakit atau keparahan penyakit pada perlakuan cendawan agens biokontrol.

\section{Rancangan Percobaan}

Penelitian disusun dalam rancangan acak lengkap dengan 13 perlakuan, yang terdiri atas kontrol, 7 perlakuan isolat Trichoderma spp. (galur T1, T2, T5, T6, T9, T10, dan T11), dan 5 perlakuan isolat Penicillium spp. (galur P1, P2, P3, P8, dan P11). Masing-masing perlakuan diulang 4 kali dengan 5 tanaman untuk masing-masing ulangan.

Data yang diperoleh dianalisis menggunakan analysis of variance, dan uji lanjut dengan uji Beda Nyata Jujur menggunakan SAS 9.0.

\section{HASIL}

Semua isolat Trichoderma spp. dan Penicillium spp. yang diuji mempunyai kemampuan sebagai penginduksi ketahanan terhadap penyakit rebah kecambah pada tanaman cabai. Kemampuan isolat-isolat tersebut menginduksi ketahanan ditunjukkan dengan nilai insidensi dan keparahan penyakit pada masing-masing perlakuan (Tabel 1 dan 2). Insidensi penyakit pada perlakuan Trichoderma spp. dan Penicillium spp. berturut-turut berkisar $0-25 \%$ dan $0-35 \%$, jauh lebih rendah dibandingkan perlakuan kontrol, yaitu $65 \%$. Penghambatan insidensi penyakit oleh isolat-isolat Trichoderma spp. mencapai $>84.6 \%$ bahkan isolat-isolat $\mathrm{T} 5$, T6, T9, T10 dan T11 mampu menghambat penyakit sebesar 100\%. Perlakuan Penicillium spp. mampu menekan insidensi penyakit sebesar $46.2-100 \%$, dengan penghambatan tertinggi $(100 \%)$ terjadi pada perlakuan P11.

Demikian pula dengan pengamatan keparahan penyakit menunjukkan bahwa perlakuan Trichoderma spp. dan Penicillium spp. sangat efektif menekan penyakit. Keparahan penyakit pada perlakuan Trichoderma spp. dan Penicillium spp berturut-turut berkisar 0-37\% dan 3-51.5\%, jauh lebih rendah dibandingkan perlakuan kontrol, yaitu 74\%. Penghambatan keparahan penyakit pada perlakuan Trichoderma spp. Berkisar $\quad 50-100 \%$ dengan penghambatan tertinggi $(100 \%)$ terjadi pada perlakuan T11. Penghambatan keparahan penyakit pada perlakuan Penicillium spp. berkisar 30.4-95.9\% dengan penghambatan tertinggi (95.11\%) terjadi pada perlakuan P11. 
Tabel 1 Insidensi penyakit rebah kecambah tanaman cabai yang disebabkan oleh Rhizoctonia solani pada perlakuan Trichoderma spp. dan Penicillium spp. terhadap insidensi penyakit

\begin{tabular}{lcc}
\hline Isolat & $\begin{array}{c}\text { Insidensi } \\
\text { penyakit* } \\
(\%)\end{array}$ & $\begin{array}{c}\text { Peng- } \\
\text { hambatan } \\
(\%)\end{array}$ \\
\hline Kontrol & $65 \mathrm{a}$ & \\
Penicillium galur P3 & $35 \mathrm{~b}$ & 46.2 \\
Penicillium galur P2 & $30 \mathrm{~b}$ & 53.8 \\
Trichoderma galur T2 & $25 \mathrm{bc}$ & 61.5 \\
Penicillium galur P1 & $20 \mathrm{bc}$ & 69.2 \\
Trichoderma galur T1 & $10 \mathrm{~cd}$ & 84.6 \\
Penicillium galur P8 & $10 \mathrm{~cd}$ & 84.6 \\
Penicillium galur P11 & $0 \mathrm{~d}$ & 100 \\
Trichoderma galur T5 & $0 \mathrm{~d}$ & 100 \\
Trichoderma galur T6 & $0 \mathrm{~d}$ & 100 \\
Trichoderma galur T9 & $0 \mathrm{~d}$ & 100 \\
Trichoderma galur T10 & $0 \mathrm{~d}$ & 100 \\
Trichoderma galur T11 & 0 d & 100 \\
\hline
\end{tabular}

*Angka yang diikuti huruf yang sama tidak berbeda nyata pada taraf $5 \%$.

Data dianalisis setelah ditransformasi arc sin.

Tabel 2 Keparahan penyakit rebah kecambah tanaman cabai yang disebabkan oleh Rhizoctonia solani pada perlakuan Trichoderma spp. dan Penicillium spp.

\begin{tabular}{|c|c|c|}
\hline Isolat & $\begin{array}{c}\text { Keparahan } \\
\text { penyakit* } \\
(\%)\end{array}$ & $\begin{array}{c}\text { Peng- } \\
\text { hambatan } \\
(\%)\end{array}$ \\
\hline Kontrol & $74 \mathrm{a}$ & \\
\hline Penicillium galur P2 & $51.5 \mathrm{~b}$ & 30,4 \\
\hline Penicillium galur P3 & $38 \mathrm{bc}$ & 48,6 \\
\hline Trichoderma galur T2 & $37 \mathrm{bc}$ & 50,0 \\
\hline Penicillium galur P1 & $26 \mathrm{~cd}$ & 64,9 \\
\hline Trichoderma galur T1 & $16 \mathrm{de}$ & 78,4 \\
\hline Penicillium galur P8 & 14 def & 81,8 \\
\hline Trichoderma galur T5 & 6 efg & 91,9 \\
\hline Trichoderma galur T9 & $5 \mathrm{fg}$ & 93,2 \\
\hline Trichoderma galur T6 & $4 \mathrm{gh}$ & 94,6 \\
\hline Penicillium galur P11 & $3 \mathrm{gh}$ & 95,9 \\
\hline $\begin{array}{l}\text { Trichoderma galur } \\
\text { T10 }\end{array}$ & $3 \mathrm{gh}$ & 95,9 \\
\hline Trichoderma T11 & $0 \mathrm{~h}$ & 100 \\
\hline
\end{tabular}

Keberhasilan reisolasi Trichoderma spp. dan Penicillium spp. dari akar yang sudah diberi perlakuan sterilisasi mencapai $10 \%$ yang menunjukkan keberhasilan mengeliminasi cendawan dari permukaan akar

\section{PEMBAHASAN}

Trichoderma spp. merupakan cendawan yang sudah banyak terbukti efektif dalam mengendalikan penyakit tanaman, terutama penyakit tular tanah dan juga menginduksi ketahanan tanaman terhadap penyakit. Harman et al. (2004) mengemukakan bahwa Trichoderma spp. merupakan cendawan yang memproduksi berbagai macam senyawa yang mampu menginduksi resistensi tanaman secara lokal dan sistemik terhadap serangan penyakit tanaman dan juga resistensi tanaman terhadap keadaan lingkungan yang tidak menguntungkan.

Djonovic (2005) melaporkan bahwa, tanaman padi, kapas, dan jagung yang diberi perlakuan Trichoderma virens pada sistem hidroponik mampu meningkatkan resistensi tanaman baik resistensi lokal maupun sistemik terhadap penyakit yang disebabkan oleh Pythium ultimum dan $R$. solani melalui small protein SM 1 (small protein 1) yang dihasilkan oleh Trichoderma virens. Singh et al. (2011) juga melaporkan bahwa perlakuan tanaman bunga matahari dengan T. harzianum mampu meningkatkan resistensi tanaman terhadap $R$. solani, dengan mekanisme yang berasosiasi dengan akumulasi ROS gene network: the catalase (CAT), superoxide dismutase (SOD), glutathione peroxidase (GPx), ascorbate peroxidase (APx), dan maximum activity of CAT. Salas-Marina et al. (2011) menambahkan bahwa, inokulasi T. atroviride pada akar Arabidopsis thaliana mampu menginduksi ketahanan tanaman terhadap serangan Botrytis cinerea dan Pseudomonas syringae pv. tomato pada bagian daun dengan ditandai adanya ekpresi gen untuk sintesis salicylic acid, jasmonic acid/ethylene, phytoalexin, dan camalexin. Trichoderma juga dilaporkan mampu meningkatkan resistensi tanaman tomat dan mentimun terhadap infeksi $R$. 
solani melalui peningkatan hydrogen peroxide $\left(\mathrm{H}_{2} \mathrm{O}_{2}\right)$, lipid peroxidation, dan aktivitas enzim phenylalanine ammonia lyase (PAL), guaiacol (POG) dan ascorbate peroxidases (APX) (Nawrocka et al. 2011)

Koike et al. (2001) melaporkan bahwa isolat cendawan PPT, seperti Trichoderma, Fusarium, Penicillium, Phoma, dan cendawan steril yang diaplikasikan pada akar tanaman mentimun dalam bentuk inokulum biji gandum, miselium, dan filtrat biakan ternyata efektif dalam menginduksi ketahanan secara sistemik pada tanaman terhadap penyakit angural leaf spot yang disebabkan oleh bakteri Pseudomonas syringae pv. lachrymans dan juga layu fusarium oleh cendawan Fusarium oxysporum f.sp. cucumerinum. Perlakuan dengan cendawan PPT ini meningkatkan sistem pertahanan tanaman melalui lignifikasi, superoxide generation, dan aktivitas chemiluminescence.

De Cal et al. (2000) melaporkan bahwa, penurunan penyakit layu fusarium pada tanaman tomat berhubungan dengan induksi ketahanan melalui aktivitas kambium dan pembentukan tambahan xilem sekunder pada tanaman tomat yang diberi perlakuan $P$. oxalicum. Hossain et al. (2008) melaporkan bahwa, tanaman Arabidopsis thaliana yang diberi perlakuan biakan sel dan filtrat Penicillium isolat GP 16-2 mampu menginduksi ketahanan tanaman secara sistemik melalui peningkatan asam jasmonat, asam salisianat, etilena, dan non-expressor of PR genes 1 (NPR1).

Perlakuan Trichoderma spp. dan Penicillium spp. pada bibit tanaman cabai sangat efektif dalam menekan insidensi dan keparahan penyakit rebah kecambah. Penelitian perlu dilanjutkan untuk mempelajari mekasnisme induksi ketahanan, yaitu secara biokimia, histologi atau genetik.

\section{UCAPAN TERIMA KASIH}

Ucapan terima kasih penulis sampaikan kepada Direktorat Pembinaan Penelitian dan Pengabdian Kepada Masyarakat, Direktorat Jenderal Pendidikan Tinggi, Departemen
Pendidikan Nasional yang telah membiayai penelitian ini dengan nomor kontrak: 026/ SP2H/PP/DP2M/III/2007.

\section{DAFTAR PUSTAKA}

De Cal A, Garcia-Lepe R, Melgarejo P. 2000. Induced resistance by Penicillium oxalicum against Fusarium oxysporum f. sp. lycopersici: histological studies of infected and induced tomato stems. Phytopathology. 90:260-268. DOI: http://dx.doi.org/10. 1094/PHYTO.2000.90.3.260.

Djonovic S. 2005. Role of two secreted proteins from trichoderma virens in mycoparasitism and induction of plant resistance [disertasi]. Texas (US): UMI.

Harman GE, Howell ChR, Viterbo A, Chet I, Lorito M. 2004. Trichoderma Species Opportunistic, Avirulent Plant Symbionts. Nat Rev. 2:43-56.

Hossain, MdM, Sultana F, Kubota M, Hyakumachi M. 2008. Differential inducible defense mechanisms against bacterial speck pathogen in Arabidopsis thaliana by plant-growth-promotingfungus Penicillium sp. GP16-2 and its cell free filtrate. Plant Soil. 304:227-239. DOI: http://dx.doi.org/10.1007/s11104-0089542-3.

Koike N, Hyakumachi M, Kageyama K, Tsuyumu S, Doke N. 2001. Induction of systemic resistance in cucumber against several diseases by plant growth-promoting fungi: lignification and superoxide generation. Eur J Plant Pathol. 107:523-533. DOI: http://dx.doi. org/10.1023/A:1011203826805.

Merra MS, Shivanna MB, Kageyama K, Hyakumachi M. 1994. Plant growthpromoting fungi from zoyusia grass rhizosophere as potential inducer of systemic resistance in cucumbers. Phytopathology. 84:1399-1406. DOI: http:// dx. doi.org/10.1094/Phyto-84-1399.

Muslim A, Horinouchi H, Hyakumachi M. 2003. Control of fusarium crown and root rot of tomato with hypovirulent binucleate Rhizioctonia in soil and rock wool systems. 
Plant Dis. 87:739-747. DOI: http://dx.doi. org/10.1094/PDIS.2003.87.6.739.

Nawrocka J, Snochowska M, Gajewska E, Pietrowska, E, Szczech M. 2011. Activation of defense responses in cucumber and tomato plants by selected polish Trichoderma strains. Veget Crops Res Bull 75:105-116. DOI: http://dx.doi. org/10.2478/v10032-011-0022-6.

Salas-marina MA, Silva-Flores MA, Uresti-Rivera EE, Castro-Longoria E, Herrera-Estrella, A. 2011. Colonization of Arabidopsis roots by Trichoderma atroviride promotes growth and enhances systemic disease resistance through jasmonic acid/ethylene and salicylic acid pathways. Eur J Plant Pathol. 131:15-26.
DOI: http://dx.doi.org/10.1007/s10658011-9782-6

Shivanna MB, Merra MS, and Hyakumachi M. 1996. Role of root colonization ability of plant growth promoting fungi in the suppression of take-all and common root rot of wheat. Crop Proec. 15:497-504. DOI: http://dx.doi.org/10.1016/0261-2194 (96)00004-X.

Singh BN, Singh A, Singh SP, Singh HB. 2011. Trichoderma harzianum - mediated reprogramming of oxidative stress response in root apoplast of sunflower enhances defence against Rhizoctonia solani. Eur J Plant Pathol. 131:121-134. DOI: http://dx.doi.org/10.1007/s10658011-9792-4. 